\title{
PROCESSES OF PUBLIC POLICY TRANSFORMATION FOR WOMEN
}

\author{
Nodira Odiljonovna Toliboeva
}

(PhD), Uzbek State University of World Languages Senior Teacher of the Department of History of Uzbekistan

\section{ABSTRACT}

The article analyzes the changes in the state policy towards women in the Republic of Uzbekistan and its main stages, the creation of the necessary legal and social guarantees for women, as well as state measures to solve social problems among women. It also highlights the responsibilities of the Mahalla and Family Support Ministry towards women.

KEYWORDS: - State policy in relation to women, treatment of women, protection of family interests, female social activism, social protection, Women's Committee, Ministry of Neighborhood and Family Support.

\section{INTRODUCTION}

Uzbekistan has become a party to more than 60 international human rights treaties, 23 of which are directly aimed at protecting the interests of women. One of the important directions of state policy is to increase the political activity of women, to create new jobs for them to solve their social problems, to increase their prestige in the economic sphere, entrepreneurship, science and technology and state building. As a result, the legal framework for the protection of women, the family, motherhood and childhood has been created.

At the same time, at a new stage of development of Uzbekistan, since women's activism plays an important role in increasing the effectiveness of reforms, more stable and dynamic development of the country, there was a need to develop forms of structural mechanisms aimed at supporting women legally and comprehensively based on an approach of treating them differently.

\section{Methods}

Methods such as historical, systematic, comparative, quantitative analysis, chronological and interdisciplinary approaches, and surveys are used in the article. A number of studies have been conducted on the role of women in the family and society, increasing their sociopolitical and economic activity, social protection, legal culture, employment, as well as women's issues. Scientists such as S.Safaeva, M.Irisova, S.Khodjaeva, E.Sultanova, A.Huseynova, G.Ganieva, N.Djuraeva are among them.

\section{Results AND Discussions}

The experience of developed countries shows that a policy based on gender equality fully 
CURRENT RESEARCH JOURNAL OF HISTORY 2(7): 34-41, July 2021

DOI: https://doi.org/10.37547/history-crjh-02-07-07

ISSN 2767-472X

(C)2021 Master Journals

\section{Crossref dof 81 Google}

Accepted $26^{\text {th }}$ July, 2021 \& Published 31 thJuly, 2021

reflects the interests of all citizens. Therefore, in order to achieve equal participation of women in society, it is necessary to provide them with more support, education and care. As the famous English sociologist E. Giddens put it: "Gender is not a physical difference between a man and a woman, but a social formation of the characteristics of a man and a woman" [1].

The creation of the necessary legal and social guarantees for women testifies to the fact that radical changes and innovations in all spheres of life of the republic have focused on the following socio-political issues related to women. In particular, to increase the status of women in society, their social and political activity, to ensure their participation in public administration, important government decisions, to increase the intellectual potential of women and to create wider and more real opportunities for their expression in various fields;

to create the necessary conditions for domestic work in accordance with social activity, to ensure employment at home, to prevent any discrimination against women in the family and society, to form a healthy mother in the country , promoting a healthy lifestyle among the population and youth;

support for women's entrepreneurship, creating opportunities for them to run small businesses and family businesses, and providing comprehensive support to women entrepreneurs [2].

One of the most pressing development challenges is to ensure the rights and interests of citizens and to achieve equality. That is why women's social activism, views on their role and status in society laid the groundwork for the achievement of equality between men and women in the international arena, the eradication of poverty and the creation of conditions for the full development of everyone.
The state policy on women in the country can be divided into 3 stages according to their content:

The first stage - the organizational and legal basis of women's socio-political activity in 1991-2000. In particular, the Women's Committee of Uzbekistan was established. A special concept for the provision of legal and social guarantees for women was developed and the committee was formally incorporated into the power structure [4]. In the Year of Women, legal acts were adopted to legally guarantee the interests of women, expand their participation in decisionmaking, and ensure their economic independence.

It is known that in the early years of independence, the main task of women's councils was to protect women from unemployment due to the closure of enterprises that could not justify themselves in a market economy, the privatization of most enterprises, the reduction of management. Therefore, in the discussion of the meeting of the Committee on Health, Women's Affairs, Motherhood and Childhood of the Supreme Council of the Republic of Uzbekistan on February 4, 1991, in order to ensure the social protection of women in the future, the following proposals were considered:

- Granting women who have worked for 20 years and raised five children the right to retire at the age of 45 ;

- Retirement at the age of 50, for those who have worked for 30 years, regardless of the number of children;

- Reduction of women's working days with full pay;

- Adoption of the Republican Law on Restriction of Child Labor in the Organization of Family Contracts;

- Increasing family responsibility through education. 
CURRENT RESEARCH JOURNAL OF HISTORY 2(7): 34-41, July 2021

DOI: https://doi.org/10.37547/history-crjh-02-07-07

ISSN 2767-472X

(C)2021 Master Journals

\section{Crossref dof 11 Google}

Accepted $26^{\text {th }}$ July, 2021 \& Published 31thJuly, 2021

Also, on March 27, 1991, at the Republican

Congress of Agricultural Workers, the employment of women at home, the opening of employment records, pensions, assistance, the creation of the necessary benefits and conditions, freeing them from hard work, the need to create a shorter working day, to create cultural and living conditions for daily life, and to eliminate shortcomings in this area as soon as possible were emphasized [6].

However, as important as the above proposals are in protecting the interests of women and the family, they have not been legally consolidated for many years.

In accordance with the Decree of the Cabinet of Ministers of the Republic of Uzbekistan dated March 1, 1991 "On the Women's Committee of the Republic of Uzbekistan" at the conference held on December 27 in Termez (Certificate No. 098) the formation of the Women's committee was also an important historical event. The main task of the Committee is to implement the state policy towards women, to increase the role of women in society, to protect their interests, to meet the various spiritual and cultural needs, as well as socio-economic, legal and moral support, protection of family, motherhood and childhood. It should be noted that in accordance with a special concept for the provision of legal and social guarantees for women, "Ecology and Women", "Social Protection of Women's Labor", "Women, Family and Community", activities within the framework of practical programs such as "Healthy generation is the basis of a healthy society" during the years of independence have had a positive impact on strengthening the status of women in the family and society and their development.

In this regard, on the basis of the Law of the Republic of Uzbekistan "On Public Organizations" in 1991, based on the goals and objectives of the Women's Committee of Uzbekistan, the Charter was revised (this Charter was approved in 1987) [8]. The charter was amended based on the goals and objectives of the committee. First, the Charter perfectly describes the main tasks of the committee, and second, it defines the main tasks of the labor collectives and the provincial, city and district women's committees. Third, the Charter sets out the legal basis for the committee's work.

According to the Special Presidential Decree No. PF-1084 of March 2, 1995 "On measures to enhance the role of women in the state and social construction of the Republic of Uzbekistan", the Chairman of the Women's Committee of Uzbekistan, 0 ' The Deputy Prime Minister of the Republic of Uzbekistan, the Chairman of the Women's Committee of the Republic of Karakalpakstan were given the status of Deputy Chairmen of the Council of Ministers, the chairmen of the Women's Committees of Tashkent city and regions were given the status of deputy governors. This ensured the formal inclusion of women's committees in the power structure and led to their participation as an active subject rather than as an object of policy. At the same time, the position of educator was established in the mahallas with the formation of a monthly salary from the local budgets for work with women and families. However, appointments to this position were not made without taking into account their qualifications and sufficient life experience. It is known that the social activity of women is determined by the reform, improvement of the socio-political and economic system and their active participation in the political process. As a result of the state's policy of care, a number of reforms have been carried out, and regulations have been adopted, but their implementation has not been fully covered.

In order to ensure the implementation of the tasks set out in the state programs adopted in connection with the years "Family", "Women", 
CURRENT RESEARCH JOURNAL OF HISTORY 2(7): 34-41, July 2021

DOI: https://doi.org/10.37547/history-crjh-02-07-07

ISSN 2767-472X

(C)2021 Master Journals

\section{Crossref dof 80 Google}

Accepted 26 ${ }^{\text {th }}$ July, 2021 \& Published 31 thJuly, 2021

"Healthy Generation", the basis for legal strengthening of the family was created, attention was paid to women's social protection and healthy mothers and children. A number of measures have been taken to implement the principle.

The second stage is 2001-2010. Within the framework of the state programs adopted on the occasion of the Year of Mothers and Children, the Year of Harmoniously Developed Generation, strengthening maternal health, strengthening attention and care for the birth of a healthy generation, women's social development in the family and society - work has been done to increase the economic status and role, to create the necessary conditions for the formation of a strong and healthy family, to strengthen the role of mother and family in the upbringing and physical and spiritual development of the child.

It is known that in 2004, in order to improve the work of the Women's Committee, the position of advisor on religious education and spiritual and moral education was introduced in citizens' assemblies. At the same time, a 30\% quota has been set in accordance with the target recommendation of the UN Commission on the Status of Women in decision-making and participation in elections. The formation of a bicameral parliament has led to an increase in women's participation in political life.

However, the number of women senators and members of the Legislative Chamber of the Oliy Majlis, as well as members of local councils of people's deputies, remained low. The reasons can be explained by:

- lack of experience in the struggle for political power among women and insufficient promotion of political career opportunities;

- insecurity of male managers towards women and the advantage of underestimating the leadership skills of female professionals;
- having difficulty obtaining the information and data necessary for the election campaign;

- lack of attention in organizations to the preparation of candidates for the reserve;

- women are a minority in government.

It is known that the Decree of May 25, 2004 No. PF-3434 "On additional measures to support the activities of the Women's Committee of Uzbekistan" created new opportunities for further development of women's activities. By this time, as a result of the rise of religious beliefs, some families were exposed to various religious-political and extremist currents, which created the need to improve the socio-spiritual environment and inculcate national values in young people. In this regard, in order to ensure the effectiveness of the Women's Committee in mahallas, the position of consultant on the issues of religious enlightenment and spiritual and moral education was introduced in particular in mahallas with at least 500 families, in settlements, villages and auls, where there are no mahallas. In 2005, in accordance with the approved Regulation on "The activities of the adviser on religious enlightenment and spiritual and moral education of citizens 'assemblies", religious enlightenment was carried out jointly with the citizens' self-government bodies. To the positions of advisers on spiritual and moral education, the most influential and active women were appointed who could influence with experience in life, which is positive for the population, especially for young people, women who could transmit decision-making on healthy lifestyles, preservation and development of exemplary national and religious traditions and customs. [11].

The Mahalla Foundation of Uzbekistan in cooperation with the Republican Administration and the Women's Committee of Uzbekistan held regional training seminars on "Religious 
CURRENT RESEARCH JOURNAL OF HISTORY 2(7): 34-41, July 2021

DOI: https://doi.org/10.37547/history-crjh-02-07-07

ISSN 2767-472X

(C)2021 Master Journals

Crossref doi 81 Google

Accepted $26^{\text {th }}$ July, 2021 \& Published 31 th July, 2021

enlightenment and improving the social and spiritual environment in the country, increasing the effectiveness of youth education. Tasks of consultants on spiritual and moral education ". During the training seminars, the specific problems of each region were studied, the assistance of qualified specialists was organized in the field, the work of consultants was carried out, and reception days for lawyers and psychologists were organized in each neighborhood.

According to the decree, the main tasks of the Women's Committee are the implementation of a national policy in the field of active participation of women in state building, the development of a set of measures to promote a healthy lifestyle, their work and study in rural areas. A number of measures have been taken to improve the living conditions of women, to develop programs aimed at attracting women to entrepreneurship, to explain and adhere to national and religious traditions, and to effectively organize efforts to combat their involvement in extremist and terrorist activities. Despite the expanding power of the Committee's work as a non-governmental organization, lack of financial resources, lack of concrete mechanisms for addressing women's issues, inadequate staffing, inexperience and lack of education have shown a negative impact on work efficiency. This is reflected in external and internal migration processes, family problems, unemployment, one-day employment (manual labourer), and increasing divorces.

Opportunities for women's greater involvement in political processes, as well as their participation in public administration and decision-making, were further expanded with the adoption of the 2008 Constitutional Law. The development of the 2010 Concept identified measures to ensure freedom of suffrage and the development of electoral legislation, increase the role of the community in ensuring social activism and strengthen the system of targeted social support, development of private entrepreneurship and family business. However, the active participation of women in public life has not been fully achieved.

The third stage is 2011-2020. At this stage, to further increase the economic activity of women, to further expand opportunities for small business and private entrepreneurship, to ensure family stability, to create an environment of high moral and spiritual values in the family, to support young families, to raise girls a number of tasks have been undertaken to assist them in acquiring, acquiring modern knowledge and professions. However, at the new stage of development of Uzbekistan, the need to address current and pending issues in the socioeconomic and spiritual spheres has led to a radical change in attitudes towards women. In accordance with the Decree "On measures to radically improve the activities in the field of support of women and strengthening the institution of the family" [12], increasing the socio-economic activity of women, strengthening their role in government and society , improving working and living conditions, guaranteeing the right to work and to further support women's entrepreneurial initiatives, radically changing their position in society and in the family, creating opportunities for combining family responsibilities with social activities, strengthening families, as well as a number of problems and shortcomings in the work were identified and a number of measures to address them were emphasized.

Lack of targeted support system for women in need of social protection and in difficult social situations, lack of practice of individual work with unemployed and socially inactive women , ineffective organization of activities to promote employment and entrepreneurship among women;

- Secondly, lack of targeted work to prepare 
CURRENT RESEARCH JOURNAL OF HISTORY 2(7): 34-41, July 2021

DOI: https://doi.org/10.37547/history-crjh-02-07-07

ISSN 2767-472X

(C)2021 Master Journals

\section{Crossref dof 81 Google}

Accepted $26^{\text {th }}$ July, 2021 \& Published 31 thJuly, 2021

young people for family life, the formation of a modern model family, its spiritual and moral foundations and strengthening traditional family values, the effectiveness of measures to prevent early marriages, family conflicts and divorces further increase;

- Third, to further strengthen the activities to protect the reproductive health of women, especially in remote rural areas, to establish an effective system for the prevention and treatment of maternal and perinatal diseases;

- Fourth, to organize effective measures for the prevention of crime and delinquency among women, as well as to further improve the legal culture of women, to strengthen the mechanisms of legal advice to modernize them;

- Fifth, the creation of organizational and staff units with the necessary authority in the system of women's committees, which will address the most important issues of women and fully mobilize their strengths and capabilities;

- Sixth, to achieve the effective implementation of the tasks assigned to it on the formation of the administrative apparatus and sources of funding of the regional branches of the Republican Research and Practice Center "Family", the study of family problems and the development of practical, science-based proposals;

- Seventh, pending issues such as preparing young people for family life, strengthening the family, improving the skills of staff in the field of conflict prevention and divorce, and the organization of their retraining were identified.

From April 1, 2018, the position of Adviser on Religious Enlightenment and Spiritual and Moral
Education of Citizens' Assemblies was transferred to the structure of district (city) women's committees on the basis of the relevant state units. The position of a specialist in working with women and strengthening the spiritual and moral values in families was introduced in each neighborhood, and in neighborhoods with more than 2,000 families, while maintaining the order of funding from the local budget. 8,800 specialists worked to improve women's family relationships, prevent conflicts, divorces, early marriages, strengthen family values, and educate women spiritually and morally.

It should be noted that the issue of gender equality in the development of the XXI century is one of the important factors in achieving the UN goals. Accordingly, the improvement and implementation of gender approaches remains a key issue in achieving social justice, equality and sustainability of citizens. Within the framework of cooperation between UN agencies in Uzbekistan, a special group on gender issues has been established, which includes representatives of almost all UN agencies. In this regard, the draft "Strategy for achieving gender equality in the Republic of Uzbekistan in 2020-2030" is being prepared and agreed with government and nongovernmental organizations. It is noteworthy that all the directions in this strategy are developed in accordance with the UN Sustainable Development Goals until 2030.

The introduction of a number of legislative changes in Uzbekistan as a measure to ensure gender equality is one of the important steps taken to make women's rights and discrimination against women a single mechanism. In particular, the laws adopted in September 2019 to protect the rights and interests of women [13], 1 Presidential Decree, 4 Presidential Decrees, 13 Cabinet of Ministers resolutions, including "Equal rights for women and men" in accordance with the Law on Guarantees of Rights and Opportunities, 
CURRENT RESEARCH JOURNAL OF HISTORY 2(7): 34-41, July 2021

DOI: https://doi.org/10.37547/history-crjh-02-07-07

ISSN 2767-472X

(C)2021 Master Journals

\section{Crossref dof 80 Google}

Accepted $26^{\text {th }}$ July, 2021 \& Published 31thJuly, 2021

Advisory Councils on gender equality have been established in all ministries and departments. In order to prevent discrimination against women, a commission on gender equality has been established in the Republic of Uzbekistan.

The various spiritual and ideological threats that are growing in the context of globalization require reforms to improve the socio-spiritual environment in society, further support the institution of the neighborhood, and improve the system of work with families and women. That is, in order to achieve efficiency in women's issues, to ensure the implementation of the tasks set out in the adopted legal acts, to radically change the mechanism of work to strengthen the activities of the Ministry of Mahalla and Family Support of the Republic of Uzbekistan began its activities. The Ministry noted that on February 18, 2020, the President of the Republic of Uzbekistan signed a decree "On measures to improve the socio-spiritual environment in society, further support the institution of the community and bring the system of work with families and women to a new level." PF-5938 and Resolution PQ-4602 "The organization of the Ministry of Mahalla and Family Support of the Republic of Uzbekistan."

Approved by the Resolution of the Cabinet of Ministers of the Republic of Uzbekistan dated April 15, 2020 No 228 on "Approval of regulatory legal acts in the field of regulation of the Ministry of Mahalla and Family Support of the Republic of Uzbekistan" The Regulation on the Ministry of Mahalla and Family Support of the Republic of Uzbekistan defines the tasks of the Ministry of Mahalla and Family Support of the Republic of Uzbekistan in supporting women [14].

In particular, to strengthen the institution of the family, first of all, to pursue a unified state policy aimed at implementing the idea of "Healthy family - healthy society", the organization of targeted assistance to troubled and troubled families;

-Ensuring the effective implementation of state policy on support of women, protection of their rights and legitimate interests, increasing their role and activity in the socio-political life of the country, guaranteeing equal rights and opportunities for women and men ;

-timely identification of women's problems, provision of social, legal, psychological and financial assistance to women in need and in difficult social situations, including women with disabilities;

-providing comprehensive support for women's employment, improving working conditions, and involving women, especially young girls in rural areas, in family and private entrepreneurship and handicrafts.

In recent years, Uzbekistan has expanded its institutional and legal framework for gender equality. Indeed, since 2019, there have been 197 Rehabilitation and Adaptation Centers for Victims of Violence in the regions. This is evidenced by the establishment of a new Committee on Women and Gender Equality, which deals with the harmonization of international standards in legislation.

\section{Conclusion}

Mechanisms to ensure state-guaranteed benefits have been established on the basis of legal and regulatory documents on social support for women. The experience of developed countries shows that a policy based on gender equality only fully reflects the interests of all citizens. Therefore, on the basis of radical changes, the public and the state are pursuing a policy of further support, education and care for women in order to increase their participation in decision-making. At the level of public policy, attention was paid to improving the quality of life of the family and ensuring social protection, 
CURRENT RESEARCH JOURNAL OF HISTORY 2(7): 34-41, July 2021

DOI: https://doi.org/10.37547/history-crjh-02-07-07

ISSN 2767-472X

(C)2021 Master Journals

Crossref dof 81 Google

Accepted $26^{\text {th }}$ July, 2021 \& Published 31thJuly, 2021

protection of motherhood and childhood. At a new stage of development in Uzbekistan, due to the need to address the social problems of women, the tasks of supporting women and strengthening the family have changed radically.

\section{ReFERENCES}

1. Lushnikov A.M., Lushnikova M.V., Tarusina N.N. Gender in the law. - Moscow: Prospect. 2014 .- S. 19.

2. UzNA. M-69 fund, list 1 , case 93 , sheet 82 .

3. UzNA. M-37 stock, list 1, case 2565, sheet 90.

4. Decree PF-1084 of March 2, 1995 "On measures to increase the role of women in the state and social construction of the Republic of Uzbekistan"// lex.uz.

5. UzNA. M-69 fund, 1st list, 88th case, 53rd sheet.

6. UzNA. M-69 fund, 1st list, 93th case, 37rd sheet.

7. UzNA. M-69 fund, 1st list, 93th case, 12rd sheet.

8. UzNA. M-69 fund, 1st list, 88th case, 53rd sheet.

9. UzNA. M-69 fund, 1st list, 88th case, 53rd sheet.

10. Decree of the President of the Republic of Uzbekistan dated May 25, 2004 "On additional measures to support the activities of the Women's Committee of Uzbekistan" // People's speech, 2004. May 30.

11. Collection of Legislation of the Republic of Uzbekistan, 2004, No. 21, Article 251. https://lex.uz/docs/214651.

12. Decree of the President of the Republic of Uzbekistan dated February 2, 2018 No PF5325 "On measures to radically improve the activities in the field of support of women and strengthening the institution of the family" (National Database of Legislation, February 3, 2018, No. 06/18/5325/0653).

13. Laws of the Republic of Uzbekistan dated September 2, 2019 on "Protection of women from oppression and violence" and on "Guarantees of equal rights and opportunities for women and men"// lex.uz.

14. National Database of Legislation, 16.04.2020, 09/20/228/0444, 07.12.2020, 09/20/772/1605. 